\title{
Effects of Career Stagnation on Performance in Public Service: A Case of Murang'a County Government
}

\author{
Bancy Ngondi Wawira ${ }^{1}$, Godrick Bulitia Mathews ${ }^{2}$, Clifford G. Machogu ${ }^{3}$, Dr. John Wekesa Wanjala ${ }^{4}$ \\ ${ }^{1}$ Administration Assistant, Murang'a County
}

${ }^{2}$ Professor, Associate Professor, Murang'a University of Technology, Human Resource Department

${ }^{3}$ Professor, Associate Professor, Murang'a University of Technology, Commerce Department

${ }^{4}$ Lecturer, Murang'a University of Technology, Human Resource Department

\begin{abstract}
Devolution is generally defined as a process of transfer of political, administrative and fiscal management powers between central government and lower levels of government, primarily operating at city and region levels (Potter, 2001). The essence of devolution is to bring services closer to the citizens. Performance of the County Government s depends on the kind of workforce they have. Performance can be affected by many factors, career stagnation being one of them. Indeed, scholars have noted that it is inevitable for employees to react to career plateau with bad performance and loss of motivation and commitment. This comes from believes that, upward movement is the benchmark to measuring performance and therefore in the absence of this, the employees become demotivated (Jang and Tak, 2008; Burke and Mikkelsen, 2006; Tremblay and Rogers, 2004). The literature reviewed has provided information on effects of career stagnation on performance elsewhere in the world by giving a global view. It is therefore recognized that this area of study still remains largely un-explored, shown by the fact that literature on career plateau in Kenya is lacking, yet the subject has a global attention evidenced by a wide array of scholars who have written on it. The research has not been conducted in Murang'a either. It is against this background that the study sought to establish the effects of career stagnation on performance in Murang'a County Government. The overall objective of the study was to establish the effects of employee career stagnation on performance in the civil service, a case study of Murang'a County Government. Specific objectives were: Establish the effects of employee career stagnation on job performance in Murang'a County Government, establish the relationship between work related stress and job performance in Murang'a County Government, establish effect of motivation on job performance in Murang'a County Government, establish the relationship between individual skills and abilities and job performance in Murang'a County Government, establish the relationship between lack of an innovative climate and job performance in Murang'a County Government. The study was guided by three theories: - the attributory theory, Donald Super's career model theory and the three factor model theory. The study adopted a survey research design. Descriptive analysis involved the use of frequencies in their absolute and relative forms (percentage). Inferential analysis was done to find out if there is any relationship between dependent and the independent variables of the study.The target population was 354 employees. The research adopted stratified random sampling design and the sample size was 178. The response rate $84 \%$ hence reliability and validity of the study. The $R$ value of the study was 0.964 and $R^{2}$ value of 0.926 . This indicates that skills and abilities to perform, motivation, an innovative climate, work stress all influences career stagnation in Murang'a County government by $92.9 \%$. The study findings suggest there is a positive correlation between all components of career plateau with a significance of 0.875 for lack of skills and abilities, 0.860 for lack of an innovative climate, 0.855 for lack of motivation and last but not least 0.659 for work related stress levels. The study concludes that the general performance of County Government has been affected by lack of necessary skills, work related stress, lack of innovative climate and lack organizational career orientation among staff members. The study recommends training of employees to equip them with necessary skills, create an innovative climate, ensure career orientation is done to all employees and work related stress in kept to the minimum. The research may be of significance to human resource practitioners within and outside Murang'a County in managing career stagnation.
\end{abstract}

Keywords: Definition of Terms: Employees: A person in the service of another under contract of hire, express or implied, oral or written where the employer has the right or power to control and direct the employee in the material detail on how the work is to be performed (Arthur, 1995). Job Satisfaction: The attitudes and feelings people have about their job. It is the degree to which an employee has positive emotions towards the job role. Organization: Refers to a social arrangement which pursues collective goals, controls its own performances and has boundary separating it from its environment (Harrison, 2005). Career Plateau/Stagnation: Career plateau is defined as the point in a career where the likelihood of additional hierarchical promotion or Lateral move is very low Job Performance: Job performance is the work related activities expected of an employee and how well those activities were executed

\section{Background of the Study}

\subsection{The Definition of the Career Plateau Concept}

Researchers in the human resources based on the classical definition of career plateau by Ference, Stoner, and Warren (1977) (Chao, 1990; Leibowitz, Kaye, Farren, 1992; Savery, 1990). Career plateau is defined as the point in a career where the likelihood of additional hierarchical promotion is very low. However, Schein (1971) had defined that career movement within an organization can be vertical, radical, or circumferential. Vertical movement can be either upward or downward. The success can be measured by the attainment of particular hierarchical levels. Personal development can be measured by a horizontal crossing of functional borders or by changing the content of any work by acquiring qualifications. In other words, this better definition of career plateau is defined as the point at which future career

Volume 6 Issue 7, July 2017

www.ijsr.net 


\section{International Journal of Science and Research (IJSR) \\ ISSN (Online): 2319-7064}

Index Copernicus Value (2015): 78.96 | Impact Factor (2015): 6.391

mobility including both upward and lateral moves (Nachbagauer\&Riedl, 2002). Ferrence et al. (1977) set a model of managerial career that describes the state of someone career based on current performance and likelihood of future promotion. The four principal career states in the model are learners or comers, stars, solid citizens, deadwood. Learners or comers describe individuals that have high potential for advancement but presently perform below standards. Obvious examples are trainees who are still learning their new jobs and are not yet integrated into the organization's culture. Stars are persons presently do outstanding work and are viewed as having for continued advancement. They are on the high potential, fast track career paths. They are readily identifiable group in organizations and receive the most attention in development programs and managerial discussion. Solid citizens presents performance is rated satisfactory to outstanding but they are seen as having little chance for future advancement. These individuals are probably the largest group in most organizations. Deadwood has little potential for advancement and their performance has fallen to an unsatisfactory level. These people have become problems whether for reasons of motivation, ability, or personal difficulty. Career plateau can be both subjective and objective.

\subsection{Statement of the problem}

Devolution is generally defined as a process of transfer of political, administrative and fiscal management powers between central government and lower levels of government, primarily operating at city and region levels (Potter, 2001).It is the decentralisation of power and resources that culminates in the formulation of sub national government units to improve efficiency, access and response to service delivery, promote participation and empowering local citizens to be more accountable. Performance of the sub national government units depends on the kind of workforce they have. Performance can be affected by many factors, career stagnation being one of them. Indeed, scholars have noted that it is inevitable for employees to react to career plateau with bad performance and loss of motivation and commitment. This comes from the believe that upward movement is the benchmark to measuring performance and therefore in the absence of this, the employees become demotivated (Jang and Tak, 2008; Burke and Mikkelsen, 2006; Tremblay and Rogers, 2004). The literature reviewed has provided information on effects of career stagnation on performance elsewhere in the world by giving a global view. It is therefore recognized that this area of study still remains largely un-explored, shown by the fact that literature on career plateau in Kenya is lacking, yet the subject has a global attention evidenced by a wide array of scholars who have written on it. It is against this background that the study sought to establish the effects of career stagnation on performance in Murang'a County Government. The overall objective of the study was to establish the effects of employee career stagnation in the civil service, a case study of Murang'a County Government and focused on the employees who are on permanent and pensionable terms of employment.

\subsection{Objectives of the study}

\subsubsection{General objective}

The general objective of the study was to establish the effects of career stagnation on performance in the civil service: A case of Murang'a County Government.

\subsubsection{Specific objectives}

The study was guided by the following specific objectives:-

1) To establish the effects of employee career stagnation on job performance in Murang'a County Government.

2) To establish the relationship between work related stress and job performance in Murang'a County Government.

3) To establish effect of motivation on job performance in Murang'a County Government.

4) To establish the relationship between individual skills and abilities and job performance in Murang'a County Government.

5) To establish the relationship between lack of an innovative climate and job performance in Murang'a County Government

\subsection{Research questions}

1) What are the effects of employee career stagnation on job performance in Murang'a County Government?

2) What is the relationship between work related stress and job performance in Murang'a County Government?

3) What is the effect of motivation on job performance in Murang'a County Government?

4) What is the relationship between individual skills and abilities and job performance in Murang'a County Government?

5) What is the relationship between lack of an innovative climate and job performance in Murang'a County Government

\subsection{Significance of the study}

The knowledge generated from this study shall contribute to the body of knowledge by provoking debate among researchers and scholars to come up with best interventions to manage career stagnation in organisations. It shall also provide substantial literature for further research. The study also seeks to extend on the literature on career stagnation in Kenya. Specifically, the human resource practitioners shall gain insight on the causes and effects of career stagnation hence are able to prevent it from happening by taking necessary precautions and also know how to deal with it. The study shall assist in policy formulation especially on training and development, staff promotions and rewards management.

\subsection{Scope and Limitations of the Study}

\subsubsection{Scope of the Study}

The case study was conducted at Murang'a County Government headquarters, located in Murang'a town, about 85 Kilometers North West of the capital city, Nairobi. Secondly, it was confined to employees working in Murang'a County head office only. 


\section{International Journal of Science and Research (IJSR) \\ ISSN (Online): 2319-7064 \\ Index Copernicus Value (2015): 78.96 | Impact Factor (2015): 6.391}

\subsubsection{Limitations of the study}

The case study was limited to one County Government though there are forty seven counties in Kenya. Hence the inferences made from the research might be challenged. However the research findings could be used as a basis for further research in the field.

Availability of respondents may also be a challenge to the study. This is attributed to the fact that most of the top management may take long to fill the questionnaires because they have very busy schedules. They are important in this research because they are the policy makers and implementers. This may highly challenge the data collection exercise owing to the stringent programs that they operate limiting their availability. The researcher shall overcome the challenge by way of liaising with the County Government administration and make prior arrangements thus assuring their availability.

Career stagnation is a worldwide phenomenon. However, the study shall only focus on Murang'a County Government employees. This is occasioned by the fact that the time and financial resources are limited.

\subsection{Assumptions of the Study}

The respondents would co-operate and provide reliable answers. The expressions given by the interviewees would be a true reflection of their opinion as to the effects of career stagnation. The variables that the study evaluated would be measurable and quantifiable. The findings of the study were pertinent to the field of Public administration. Assessment of effects of career stagnation among civil servants, specifically in Murang'a County Government had not been undertaken before. The research findings will encourage formulation of Human Resource policies especially on recruitment and training. Lastly, the research recommendations will be taken in to account to manage stagnation in Murang'a County and any other organization/County that is experiencing Career plateau.

\subsection{Conceptual framework}

A conceptual framework is a written or visual presentation that, explains either graphically, or in narrative form, the main things to be studied: the key factors, concepts or variables and the presumed relationship among them Miles and Huberman (1994). (Bodgan, 2007) defined conceptual framework as a set of broad ideas and principles taken from relevant fields of enquiry and used to structure a subsequent presentation. The independent variable is career stagnation measured by stress levels, motivation, individual skills and abilities, and organizational career orientation. The dependent variable is Performance, measured by efficiency in service delivery, revenue collection, employee job satisfaction and project completion. The independent variable; career stagnation is expected to influence performance which is the dependent variable. It is on the basis of this interaction that the research questions were formulated and answered satisfactorily.

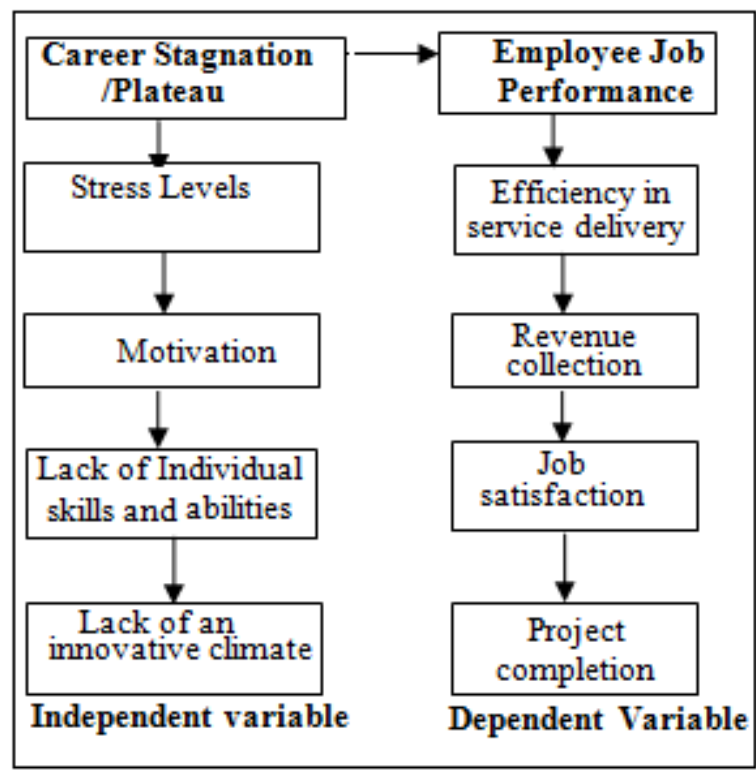

Figure 1: Effects of career stagnation on Performance Source: self-conceptualization (2017)

\section{Literature Review}

This chapter gives a review of the available theoretical and empirical literature, critique of the existing literature relevant to the study, summary of the literature review and the research gaps.

\subsection{Theoretical framework}

Theoretical literature is the theories which shall guide this study.

\subsubsection{Attribution Theory}

The attribution theory was introduced by Fritz (1958) and aimed at evaluating how individuals identify the behavior of themselves as well as of their colleagues Heider, (2013). Attribution theory describes how individuals assume casual explanations. Heider (1958) argued that people are motivated by two primary needs. The need to form a coherent view of the world and the need to gain control over the environment. He also indicated that individuals were like amateur scientists who took the role of understanding each other's behaviour through collecting information until they came up with a reasonable explanation Malle (2008).

\subsubsection{Super's Career Development Theory}

Donald E. Super's (1994) career development theory is termed to be among the most widely known life-span opinion of career development Savickas (1995). Development theories possess knowledge on the changes that individuals face as they mature while also emphasize on a lifespan approach towards career choice as well as adaptation. In Super's theory, the environmental, personal and situational determinants play a role in shaping and employees career growth and also Burke(2006) approach to career stagnation as they capture a wide range of aspects that affect both the employee and the organization. 


\section{International Journal of Science and Research (IJSR) \\ ISSN (Online): 2319-7064 \\ Index Copernicus Value (2015): 78.96 | Impact Factor (2015): 6.391}

\subsubsection{The three factor model}

This model thought that the determinants of hieratical plateau could be divided into three broad categories: individual, familial and organizational factors. The first are linked to the specific situations of the individuals themselves: age, tenure, and focus of control, education level, a lack of skills or ambition et.al. The second set of factors includes family satisfaction, family scale, family load, the spouse's type of work et.al. The third set of factors involves structural characteristics and career path -staff or line position. Tremblay and Roger empirically validated the three-factor casual model Tremblay, Roger (1993).

\subsection{Empirical review}

Empirical literature involves what other writers and researchers have written concerning the effects of career stagnation in public sector.

\subsubsection{Lack of employee individual skill and abilities and Performance}

One major source of stress leading to career plateau is the nature of interpersonal relationships on the job. Some jobs require a great deal of interactions with others. Over time, people can become burned out by the hassles and frictions of daily due interactions episodes. (dohrenwennd et.al. 1985 ; Lazarus et.al, 1975). This is exacerbated when the client the employees are interacting with are in distress themselves. Individual employees possess some level of proficiency at performing a particular task and have a more general enduring capability. Lack of individual skill and abilities may cause career plateau. Individual having skill and abilities means, the individual has an individual's level of proficiency at performing a particular task and has a more general enduring capability that an individual possesses (Noe, Hollenbeck, Gerhart, Wright, 2008). This is in such a way that skill and ability are characteristics about people that are observable only when individuals are carrying out a task, duty, and responsibility.

\subsubsection{Lack of motivation and Performance}

A sound revenue system for local governments is an essential pre-condition for the success of fiscal decentralization (Bird 2010; Martinez-Vázques and Smoke 2010a; Olowu and Wunsch 2003). Motivated employees in a work setting are described as workers who perform a job just to obtain achievement irrespective of the reward. These individuals achieve satisfaction by performing well and usually have the ultimate goal of their career as psychological success, the feeling of pride and personal accomplishment that comes from achieving one's most important goals in life.

\subsubsection{Lack organization innovative climate and Performance}

Organizations that encourage innovation end up with great project, motivated staff and there is usually no room for stagnation. Innovation is that process which involves the generation and implementation of ideas. In an organization this shall include looking out for new technologies, processes, techniques, or product ideas; generating and encouraging new creative ideas; promoting and championing ideas to others; investigating and securing funds needed to implement new ideas and lastly developing adequate plans and schedules for the implementation of new ideas. These behaviors can be developed through building Organization innovative climate. At the individual level climate signals that individuals receive concerning organizational expectations for behavior and potential outcomes of behavior (Amabile\&Gryskiewicz, 1989).

\subsubsection{Increased stress levels and Performance}

Stress is a prevalent problem in organization life and it can influence career development. Both individuals and organizations have been aware of the threats posed by excessive stress on employees. Individuals who experience high levels of perceived stress often report poor physical health, depression, and insufficient job satisfaction (Tweed et al, 2004). For organizations, reduced productivity, high turnover, frequent tardiness and absenteeism are common of consequences of workplace stressors (Elferinget al., 2005). There are career development obstacles including personal ambitions, unfair promotion system, and limited promotion which can put individuals under pressure because they think that they are unable to move forward in their career and that they are unfairly treated consequently, individuals are depressed (Elferinget al. 2005). The feeling of depression is due to the unfulfilling needs of individual expectation of having a good career.

\subsection{Research Gap}

Literature reviewed provided information on the types of plateaus and how they are experienced and causes of plateaus as seen elsewhere in the world by giving a global view. Literature on effects of career stagnation in Kenya is not sufficient, yet the subject has a global attention evidenced by a wide array of scholars who have written on it. A research on career stagnation has not been conducted in Murang'a County before either. From the Kenyan scenario, what are the effects of career stagnation on performance and whether it has improved or worsened with devolution? This study therefore attempted to fill this gap.

\section{Methodology}

The study adopted the survey research design. The study was conducted in Murang'a County Government, which is in the former central Province of Kenya. The target population was the permanent employees of the Murang'a County Government who have worked for over four years in the civil service or defunct local authorities. The study used stratified random sampling technique to select samples that were representative of the entire population. For the purpose of this study, the sample size was considered at four levels of analysis: top level management, middle level management, lower level management and support staff. The sample size of this study therefore comprised of a total of one hundred and seventy eight (178) respondents. The margin of error was 5\% and the confidence level $95 \%$

The sample size of this study was therefore comprised of a total of one hundred and seventy eight (178) respondents. Primary data was collected through questionnaires and interviews while secondary data was obtained from written materials including books, journals and newsletters. Data

\section{Volume 6 Issue 7, July 2017




\section{International Journal of Science and Research (IJSR) \\ ISSN (Online): 2319-7064}

Index Copernicus Value (2015): 78.96 | Impact Factor (2015): 6.391

was collected by use of questionnaire. The data collected was edited and coded thematically and analyzed using the statistical software package SPSS to generate descriptive and inferential statistics while secondary data was subjected to content analysis Pajares (2007). The data collected was presented using tables to summarize the data for ease of understanding.

\section{Research Finding and Discussion}

\subsection{Questionnaire return rate}

178 questionnaires were issued to the respondents and out of these 150 questionnaires were filled correctly and returned. 20 questionnaires were not returned while 8 of them were spoiled. This was 84 percent which the researcher felt was enough representation. The female population consisted of $40 \%$ of the entire respondents who returned their questionnaires while the male percentage was $60 \%$. The information in the table indicates that both female and male were appropriately represented in the study.

\subsubsection{Age}

Table 4.2: Age distribution

\begin{tabular}{|c|c|c|c|c|c|}
\hline & & Frequency & Percent & $\begin{array}{c}\text { Valid } \\
\text { Percent }\end{array}$ & $\begin{array}{c}\text { Cumulative } \\
\text { Percent }\end{array}$ \\
\hline \multirow{4}{*}{ Valid } & $18-35$ & 90 & 60 & 60 & 60 \\
\hline & $36-45$ & 40 & 26.7 & 26.7 & 26.7 \\
\hline & $46-60$ & 20 & 13.3 & 13.3 & 100 \\
\hline & Total & 150 & 100 & 100 & \\
\hline \multicolumn{2}{|c|}{ Total } & 150 & 100 & & \\
\hline
\end{tabular}

Source: Author (2017)

From the above table, people aged between 18-35 years comprised of $60 \%$ of the respondents, those aged between 36-45 years were $26.7 \%$. Respondents aged 46-60 years represented $13.3 \%$ of the total respondents which is attributed to the fact that majority of members under this age bracket occupy senior positions in the department and others have exited the employment.

\subsubsection{Education level}

Table 4.3: The education level

\begin{tabular}{|c|c|c|c|c|c|}
\hline & & Frequency & Percent & $\begin{array}{c}\text { Valid } \\
\text { Percent }\end{array}$ & $\begin{array}{c}\text { Cumulative } \\
\text { Percent }\end{array}$ \\
\hline \multirow{4}{*}{ Valid } & Primary & 10 & 6.7 & 6.7 & 6.7 \\
\cline { 2 - 6 } & Secondary & 40 & 26.7 & 26.7 & 33.4 \\
\cline { 2 - 6 } & Diploma & 50 & 33.3 & 33.3 & 66.7 \\
\cline { 2 - 6 } & Degree & 40 & 26.7 & 26.7 & 93.4 \\
\cline { 2 - 6 } & Masters & 9 & 6 & 6 & 99.4 \\
\cline { 2 - 6 } & PhD & 1 & 0.6 & 0.6 & 100 \\
\cline { 2 - 6 } & Total & 150 & 100 & 100 & \\
\hline g & System & 0 & 0 & & \\
\hline \multicolumn{7}{|c|}{ Total } & 150 & 100 & & \\
\hline
\end{tabular}

\section{Source: Author (2017)}

From the study, respondents with education qualification of primary education comprised $6.7 \%$ of the total respondents; secondaryeducation comprised $26.7 \%$, diploma comprised $33.3 \%$, degree were $26.7 \%$ masters were $6 \%$ while $\mathrm{PhD}$ level of education were of $0.6 \%$.

\subsection{Level of Employment}

\begin{tabular}{|c|c|c|c|c|c|}
\hline & & Frequency & Percent & Valid & Cumulative \\
Percent & Percent \\
\hline \multirow{4}{*}{ Valid } & Top management & 20 & 13.3 & 13.4 & 13.4 \\
\cline { 2 - 6 } & Middle level & 40 & 26.7 & 33.3 & 46.7 \\
\cline { 2 - 6 } & Lower level & 30 & 20 & 53.3 & 100 \\
\cline { 2 - 6 } & Support Staff & 60 & 40 & & \\
\cline { 2 - 6 } & Total & 150 & 100 & 100 & \\
\hline \multicolumn{7}{|c|}{ Total } & 150 & 100 & & \\
\hline
\end{tabular}

\section{Source: Author (2017)}

The table above shows that $13.3 \%$ of the employees are in top management level, $26.7 \%$ are in middle level management, lower level management $20 \%$, and lastly the support staff at $40 \%$.

\subsection{Work Experience}

The study required data on the work experience of the respondents as shown in the table below;

Table 4.5: Work experience

\begin{tabular}{|c|c|c|c|c|c|}
\hline & & Frequency & Percent & $\begin{array}{c}\text { Valid } \\
\text { Percent }\end{array}$ & $\begin{array}{c}\text { Cumulative } \\
\text { Percent }\end{array}$ \\
\hline \multirow{5}{*}{ Valid } & 5-Jan & 60 & 40 & 40 & 40 \\
\cline { 2 - 6 } & 10-May & 50 & 33.3 & 33.3 & 73.3 \\
\cline { 2 - 6 } & 15-Oct & 30 & 20 & 20 & 93.3 \\
\cline { 2 - 6 } & ABOVE 15 & 10 & 6.7 & 6.7 & 100 \\
\cline { 2 - 6 } & Total & 150 & 100 & 100 & \\
\hline \multicolumn{2}{|c|}{ Total } & 150 & 100 & & \\
\hline
\end{tabular}

\section{Source: Author (2017)}

The above table shows that $40 \%$ of the respondents had worked for not more than two year, $33.3 \%$ had worked between five-ten years, $20 \%$ of the respondents have worked for between ten-fifteen years while $6.7 \%$ had worked for more than fifteen years.

4.6 Inferential statistics on skills, motivation, innovation, stress on stagnation 


\section{International Journal of Science and Research (IJSR) \\ ISSN (Online): 2319-7064}

Index Copernicus Value (2015): 78.96 | Impact Factor (2015): 6.391

Table 4.6: Correlations of factors affecting performance

\begin{tabular}{|c|c|c|c|c|c|c|}
\hline & & $\begin{array}{c}\text { Lack of } \\
\text { skills }\end{array}$ & $\begin{array}{c}\text { Lack of } \\
\text { motivation }\end{array}$ & $\begin{array}{c}\text { Lack of } \\
\text { innovation }\end{array}$ & $\begin{array}{c}\text { Increased } \\
\text { stress }\end{array}$ & $\begin{array}{c}\text { Career } \\
\text { stagnation }\end{array}$ \\
\hline \multirow{3}{*}{$\begin{array}{l}\text { Lack of } \\
\text { skills }\end{array}$} & Pearson Correlation & 1 & $793^{* *}$ & $.900^{* *}$ & $.793^{* *}$ & $.859^{* *}$ \\
\hline & Sig.(2 tailed) & & 0 & 0 & 0 & 0 \\
\hline & $\mathrm{N}$ & 150 & 150 & 150 & 150 & 150 \\
\hline \multirow{3}{*}{$\begin{array}{c}\text { Lack of } \\
\text { motivation }\end{array}$} & Pearson Correlation & $.793^{* *}$ & 1 & $.924^{* *}$ & $.862^{* *}$ & $.902^{* *}$ \\
\hline & Sig.(2-tailed) & 0 & & 0 & 0 & 0 \\
\hline & $\mathrm{N}$ & 150 & 150 & 150 & 150 & 150 \\
\hline \multirow{3}{*}{$\begin{array}{c}\text { Lack of } \\
\text { innovation }\end{array}$} & Pearson Correlation & $.900^{* *}$ & $.924^{* *}$ & 1 & $.897^{* *}$ & $.908^{* *}$ \\
\hline & Sig.(2-tailed) & 0 & 0 & & 0 & 0 \\
\hline & $\mathrm{N}$ & 150 & 150 & 150 & 150 & 150 \\
\hline \multirow{3}{*}{$\begin{array}{c}\text { Increased } \\
\text { Stress }\end{array}$} & Pearson Correlation & $.793^{* *}$ & $.862^{* *}$ & $.897^{* *}$ & 1 & $.871^{* *}$ \\
\hline & Sig. (2-tailed) & 0 & 0 & 0 & & 0 \\
\hline & $\mathrm{N}$ & 150 & 150 & 150 & 150 & 150 \\
\hline \multirow{3}{*}{$\begin{array}{c}\text { Career } \\
\text { stagnation }\end{array}$} & Pearson Correlation & $.859^{* *}$ & $.902^{* *}$ & $.908^{* *}$ & $.871^{* *}$ & 1 \\
\hline & Sig. (2-tailed) & 0 & 0 & 0 & 0 & \\
\hline & $\mathrm{N}$ & 150 & 150 & 150 & 150 & 150 \\
\hline
\end{tabular}

Source: Author (2017)

Correlation among the independent variables is illustrated by the matrix in table 4.6. Correlation is often used to explore the relationship among a group of variables (Pallant, 2010) in turn helping in testing for multi-collinearity. That the correlation values are not close to 1 or -1 is an indication that the factors are sufficiently different measures of separate variables (Farndale, Hope-Hailey and Kelliher, 2010). It is also an indication that the variables are not multi-collinear. Absence of multi-collinearity allows the study to utilize all the independent variables. Table 4.6 shows that the lowest correlation in this study was between lack of skills and career stagnation $(r=0.567, p<0.00)$. The highest correlation was between increased stress level and career stagnation $(\mathrm{r}=0.871, \mathrm{p}<0.00)$. A correlation of above 0.871 is a strong indication that the variables may be measuring the same thing (Tabachnick and Fidell, 2013). The fact that only one variable was close to 0.90 was a clear indication that the factors were sufficiently different measures of separate variables, and consequently, this study utilized all the variables.

\subsubsection{Regression on independent and dependent variables}

Multiple regressions were done since the study had more than one independent variable to find out whether the independent variables together predict a given dependent variable (Mugenda and Mugenda, 2010) i.e. stress levels, motivation, innovative climate, individual skills, all influence performance in the Murang'a County Government.

\subsection{Effects of Skills, Motivation, Innovation and Stress on career stagnation}

\begin{tabular}{|c|c|c|c|c|r|}
\hline \multirow{2}{*}{ Model } & \multirow{2}{*}{$\mathrm{R}$} & R Square & $\begin{array}{c}\text { Adjusted R } \\
\text { Square }\end{array}$ & $\begin{array}{c}\text { Std. Error of the } \\
\text { Estimate }\end{array}$ & \\
\cline { 5 - 6 } & & & R Square C \\
\hline 1 & $.964^{\mathrm{a}}$ & 0.929 & 0.926 & 0.306 & 0.929 \\
\hline
\end{tabular}

The R Squared regression can range from 0.000 to 1.000 , with 1.000 showing a perfect fit that indicates that each point is on the line (Carver, 2009). From the above table coefficient correlation $\mathrm{R}$ value is the correlation of determination, $\mathrm{R}^{2}$ is the coefficient of determination and the standard error of estimate is 0.926 . $R$ value of 0.964 is a good estimate ratio of the career stagnation by the independent variables i.e. skills, motivation, innovation, and stress. The study findings revealed that the positive relationship between the selected dependent variables and the independent variables as depicted by coefficient of determination (R) of 0.964., and Correlation Coefficient (RSquare) of 0.929 ( career stagnation is explained by skills, motivation, innovation, and stress while the other 0.071 is presented by other unexplained variables. This implies that the independent variables are good estimators of career stagnation in Murang'a County Government. This indicates that skills, motivation, innovation, and stress influences career stagnation in Murang'a County Government by $92.9 \%$.

\section{Lack of skills and career stagnation}

\begin{tabular}{|c|c|c|c|c|c|c|c|c|c|}
\hline \multicolumn{10}{|c|}{ Model Summary of lack of skills and career stagnation } \\
\hline \multirow{2}{*}{ Model } & \multirow{2}{*}{$\mathrm{R}$} & \multirow{2}{*}{ R Square } & \multirow{2}{*}{$\begin{array}{c}\text { Adjusted R } \\
\text { Square }\end{array}$} & \multirow{2}{*}{$\begin{array}{l}\text { Std. Error of the } \\
\text { Estimate }\end{array}$} & \multicolumn{5}{|c|}{ Change Statistics } \\
\hline & & & & & R Square Change & F Change & f1 & $\mathrm{f} 2$ & Sig. F Change \\
\hline 1 & $.936^{\mathrm{a}}$ & 0.875 & 0.875 & 0.399 & 0.875 & 900.112 & 1 & 128 & 0 \\
\hline \multicolumn{10}{|c|}{ Source: field data (2017) } \\
\hline
\end{tabular}

From the above table $\mathrm{R}$ squared is 0.875 implying $87.5 \%$ change in the employee skills affects career advancement. 
International Journal of Science and Research (IJSR)

ISSN (Online): 2319-7064

Index Copernicus Value (2015): 78.96 | Impact Factor (2015): 6.391

Lack of motivation and career stagnation

\begin{tabular}{|c|c|c|c|c|c|c|c|c|c|}
\hline \multicolumn{10}{|c|}{ Model Summary of lack of motivation and career stagnation } \\
\hline \multirow{2}{*}{ Model } & \multirow{2}{*}{$\mathrm{R}$} & \multirow{2}{*}{ R Square } & \multirow{2}{*}{\begin{tabular}{|c|} 
Adjusted R \\
Square
\end{tabular}} & \multirow{2}{*}{$\begin{array}{l}\text { Std. Error of the } \\
\text { Estimate }\end{array}$} & \multicolumn{5}{|c|}{ Change Statistics } \\
\hline & & & & & R Square Change & F Change & $\mathrm{f} 1$ & $\mathrm{f} 2$ & Sig. F Change \\
\hline 1 & $.925^{\mathrm{a}}$ & 0.856 & 0.855 & 0.429 & 0.856 & 763.222 & 1 & 128 & 0 \\
\hline
\end{tabular}

From the above table $\mathrm{R}$ squared is 0.855 implying that $85.5 \%$ change in motivation affects career advancement and the relationship between the two variables is very strong indicated by sig. F calculate 0.000 . Meaning it is very significant.

Innovative climate and career stagnation

Model Summary of innovative climate and career stagnation

\begin{tabular}{|c|c|c|c|c|} 
Model & $\mathrm{R}$ & $\mathrm{R}$ Square & $\begin{array}{c}\text { Adjusted R } \\
\text { Square }\end{array}$ & $\begin{array}{c}\text { Std. Error of the } \\
\text { Estimate }\end{array}$ \\
\hline 1 & $.927^{\mathrm{a}}$ & 0.86 & 0.859 & 0.424 \\
\hline \multicolumn{5}{|c|}{ Source: Field data (2017) } \\
\hline
\end{tabular}

From the above table, R squared is 0.860 implying that $86 \%$ change in the innovative climate leads to career advancement.

Stress level and career stagnation

\begin{tabular}{|c|c|c|c|c|}
\hline \multicolumn{4}{|c|}{ Model Summary of stress level and career stagnation } \\
\hline Model & $\mathrm{R}$ & R Square & $\begin{array}{c}\text { Adjusted } \\
\text { R Square }\end{array}$ & $\begin{array}{c}\text { Std. Error of } \\
\text { the Estimate }\end{array}$ \\
\hline 1 & $.689^{\mathrm{a}}$ & 0.68 & 0.659 & 0.424 \\
\hline \multicolumn{5}{|c|}{ Source: Field data (2017) } \\
\hline
\end{tabular}

From the above table, $\mathrm{R}$ squared is 0.659 implying that $65.9 \%$ change in work related stress levels affects career advancement.

\section{Summary of Findings}

For the employee to advance in the career ladder there must be various measures to be in place which include acquisition of required skills, motivational climate, career orientation, innovative climate, and less stress. The outcome of the study indicated that career stagnation has been majorly contributed by lack of required skills and ability, motivational climate, lack of an innovative climate and increased stress levels

\subsection{Findings on influence of lack of skills on career stagnation.}

Owing to the finding there was a strong positive relationship (Correlation of 0.567 ) between career stagnation and lack of skills based on the indicators used. There was the need to ensure that the employee skills within the organization conform to requirements. Skilled employees are confident and ready to face new challenges. Their performance is high and promotional chances enhance especially where performance is a key indicator. These skills will enable the implementation of the required career advancement, to achieve the desired career development. Effective skills enhance stability of institution needs to successfully deliver career advancement effectively as well as maintaining its competitive edge. Therefore the organizations and employees must ensure acquisition of necessary skills to enable career advancement as argued by noel et al, (2012).

\subsection{Findings on effect of lack of motivation and career} stagnation

The findings indicate that there is a strong positive correlation between lack of motivation and career stagnation. Employee motivation significantly influences career advancement within the institution as indicated by Lemireet al(2015). Lack of motivation leads to career stagnation while motivation enhance career advancement. Organizations should encourage motivational climate in order to achieve career advancement to their employees.

\subsection{Findings on innovation climate}

From the findings there was a correlation of 0.479 meaning a positive relationship exist between innovative climate and career stagnation in the Murang'a in Murang'a County Government. The county has not invested in looking out for new technologies, processes, techniques, or product ideas; generating and encouraging new creative ideas; promoting and championing ideas to others; investigating and securing funds needed to implement new ideas and lastly developing adequate plans and schedules for the implementation of new ideas. Without adequate innovative climate, the implementation of career advancement is not possible. The indicator used shows that innovative climate plays a key role in the career advancement.

\subsection{Findings on stress levels}

From the findings there was a correlation of 0.853 meaning a positive relationship exist between increased stress and career stagnation in the Murang'a in Murang'a County Government. A stressed employee cannot be productive. They always seek reasons to be absent from work, they lack necessary concentration required for optimum performance. When an employee's career has stagnated, they feel stressed and frustrated. High stress levels can also make them relactact to learn or even go for opportunities hence stagnation. Basing on the indicator used, increased stress plays akey role in the career stagnation which affects performance.

\section{Conclusion and Recommendations}

\subsection{Conclusions}

Employees expect to develop in their career ladder from time of recruitment up to time of retirement. This has not been the case for some employees, especially in Murang'a County Government; there are quite a number of employees who have stagnated in one post for many years. It was established that career stagnation in Murang'a County Government is due to the following: some of the employees are stagnated because of lack of necessary skills to enable them tackle more challenging tasks, the structure is yet to be 


\section{International Journal of Science and Research (IJSR) \\ ISSN (Online): 2319-7064 \\ Index Copernicus Value (2015): 78.96 | Impact Factor (2015): 6.391}

streamlined and therefore employees from the defunct local authority cannot be promoted since some positions do not exist in the new establishment, also there is an issue of motivation where the management has not encouraged employees to utilize available opportunities for advancement, lastly but not least there is increased stress level as employees are overworked and has environment leading to career stagnation. Due to stagnation, the efficiency in service delivery to citizens has been affected. The revenue collection is not high due to demotivation. The revenue collectors have been on casual employment for years. There is very little job satisfaction due to lack of skills and abilities. The delivery of county projects has been affected greatly and timeline are never met due to lack of skills, lack of innovative climate and work related stress.

\subsection{Recommendations}

Based on the analysis of the study, the study wishes to make the following recommendations;

1) The employees should be encouraged and supported to acquire more skills in order to enhance their chances of being promoted. Well balance training programmes should be prepared and implemented effectively.

2) The employer should set motivational climate by being approachable, embracing participative decision making, introduce various non-monetary and monetary rewards, provide career development talks so as the employees are well equipped with necessary requirements.

3) Internal recruitment should be encouraged to give growth opportunities to many of the employees who have stagnated because their positions do not exist in the new establishment if they have the necessary qualifications.

4) Innovative ideas should be encouraged and supported in order to come up with great projects which can transform the lives of the citizens of Murang'a County. Management should set aside a reasonable amount of money to facilitate/support innovation.

5) Employees should be assigned reasonable work to avoid stressing them up with so many tasks. They should be guided and counseled on the way to minimize stress at work place so that they concentrate on core mandate which will lead to career development, advancement and better performance. A counseling office is necessary to counsel on both work related and personal issues affecting employees.

\section{Suggestions for Further Studies}

The research did not exhaust all the models that contribute to career stagnation. Further research can be done on the causes of career stagnation in Murang'a County. It is also suggested that a study is carried out on effects of career stagnation on performance in the private sector.

\section{References}

[1] Andreas G M, Riedl g, (2000).Causes of concepts of career stagnations on performance, work satisfaction and commitment. International journal of manpower, 23(8):.716-733

[2] Appelbaum S H, santiago v (1997). Career development in the potential organisations.International journal of career development. 2(1):11-20

[3] Armstrong Michael, (2006). A handbook of human resource management practice, $10^{\text {th }}$ Edition

[4] Amabile, T, M \&Gryskiewicz, n. 1989. The creative environment scales: the work environment inventory. Creativity research journal, 2: 231-254.

[5] Bardwick J M (1988).the plateauing trap, bantam books, toronto, pp. 17-164

[6] Bourgeois R P \&Wils T (1987). Career concepts, personality and values of some canadian workers: an exploratory study. Relations /industries, 42: 528-542.

[7] Burke R J, Mikkelsen A (2006). Examining the career stagnation among police officers. International journal of police strategies and management, 29 (4):691-703

[8] Burke, R. J., \&Mikkelsen, A. (2006).Examining the career plateau among police officers. Policing: An International Journal of Police Strategies \& Management, 29(4), 691-703.

[9] Chao, G.T. 1990. Exploration of the conceptualization and measurement of career stagnation: a comparative analysis. Journal of management, 16: 181-193.

[10]Chau, C.(1998). Career stagnations.The internal auditors, 55: 48-52.

[11] Cooper, D. R., Schindler, P. S., \& Sun, J. (2006). Business research methods.

[12]Ference, T.P., Stoner, J.A.F., Warren, E.K. 1977. Managing the career stagnation, academy of management review, 2: 602-612.

[13] Gattiker, U.E., \&Larwood, L. 1990. Predictors for career achievement in the corporate hierarchy. Human relations, 43: 703-726.

[14] Gunz H (1989). Career and corporate cultures, basil blackwell, oxford

[15] Hall, D T. 1996. Protean careers of the 21st century. The academy of managementreview, 37:

[16] Heider, F. (2013). The psychology of interpersonal relations.Psychology Press.

[17] Heider, F. (1958). The Psychology of Interpersonal Relations. New York: Wiley.

[18] Hurst, C. S., Kungu, K., \&Flott, P. (2012). Stress, organizational citizenship behaviors, and coping: Comparisons among plateaued and non-plateaued employees. Business and Management Research, 1(3), p17.

[19]Jang J, Tak J (2008). Perceived career stagnation on employee's attitudes. J. Career deve. 35(2):187-20

[20] Jon M. Werner, Randy L. Desimone. Human resource development.Accessed http://www.hrcrossing.com/article/270059/stuck-on-acareer-plateau/journalofmanagement development, 17: 392-401.

[21] Kahnweiler, W M. 2006. Sustaining success in human resources: key career self-management strategies.Human resource planning, 29: 24-31.

[22] Lee P.C.B (2003). Going beyond career stagnation: using professional plateau to account for work outcomes.Journal of management development, 22: 538-551.

[23] Leibowitz, Z B., Kaye, B.L., \&Farren, C. 1990. What to do about career gridlock.

[24] Lemire, L., Saba, T., \& Gagnon, Y. 1999. Managing career plateau in the public sector. Public personnel management, 28: 375-390

\section{Volume 6 Issue 7, July 2017




\section{International Journal of Science and Research (IJSR) \\ ISSN (Online): 2319-7064 \\ Index Copernicus Value (2015): 78.96 | Impact Factor (2015): 6.391}

[25] Lapalme, M. Ė., Tremblay, M., \& Simard, G. (2009). The relationship between career plateauing, employee commitment and psychological distress: The role of organizational and supervisor support. The International Journal of Human Resource Management, 20(5), 11321145.

[26] Mayasari, I. (2008). Managing Career Plateau Professionally In Organization Setting.

[27] Malle, B. F. (2008). Fritz Heider's legacy: Celebrated insights, many of them misunderstood. Social Psychology, 39(3), 163-173.

[28] Meyer, J.P., \& Allen, N. J. 1991.A three component conceptualization of organizational commitment.Human resource management review, 1: 61-89.

[29] Miles, R.E., \& Snow, C.C. 1977. Organizational strategy, structure, and process.ew

[30] Mitchell, T.R., Smyser, C.M., \& Weed, S.E. 1975. Locus of control: supervision and work satisfaction. Academy of management journal, 18: 623-631.

[31] Mugenda\&Mugenda, (2003).Research Methods Quantitative and Qualitative ApproachesActs Press, Nairobi, Kenya.

[32] Mugenda, O. M., \&Mugenda, A. G. (2012).Research methods dictionary.

[33] Nachbagauer, A.G.M., \&Riedl, G. 2002. Causes of concepts of career stagnations on performance, work satisfaction, and commitment.International journal of manpower, 23: 716-733.

[34] Nicholson, N. 1993.Purgatory or place of safety?The managerial plateau and organizational agegrading.Human relations, 46: 1369-1389.

[35]Noe, R.A., Hollenbeck, J.R., Gerhart, B., \& Wright, P.M. (2008) human resourcereview, 24:67-73

[36] Noe, R., Hollenbeck, J., Gerhart, B., Wright, P., Athanassopoulos, C. G., \&Delitheou, V. (2008).Management of Human Resources. Volume $A^{\prime}$ and $B$.

[37] Pajares, F. (2007).Elements of a proposal. Emory University (http://www. des. emory. edu/mfpl/proposal. html) accessed, 13, 11-12.

[38] Patterson le, sutton re, schuttenberg e m (1987). Plateaued careers, productivity and career satisfaction of college education faculty. Career development quarterly, 35 (3):197-205

[39] Rita M.C, lawsonks (1998). Employee plateauing: some wormcgace attitudes. Journal of management. 17 (6):392-401

[40] Savickas, M. L. (1995). Donald E. Super (19101994). The Counseling Psychologist, 23(2), 370-372.

[41] Salami, S. O. (2010). Career plateauing and work attitudes: Moderating effects of mentoring others with Nigerian employees. Europe's Journal of Psychology, 6(4), 71-92.

[42] Savery, L.K. 1990. Managing plateaued employees. Management decisions, 28: 46-50. Scott,

[43] Shaw, D.J., Gupta, N., Mitra, A., Ledford, g.e. 2005. Success and survival of skill basedpay plans. Journal of management, 31: 28-49.

[44] Slocum, J.W., Cron, W.L., Hansen, R.W., \& Rawlings, S. 1985. Business strategy and the management of plateaued employees.Academy of management journal, 28:

[45] Snacke, M., Shalliams, R. J, fredenberger, w.
2007.Relationship between frequency of use career management practices and employee attitude, intention to turnover, and job search behavior.Journal of organization culture, communication, and conflict, 11: 53-64

[46] Sneel S, Bohander g (2007). Human resource management, international student edition. Thomson higher education, mason, oh 45040, usa. (isbn-13-9780-324-42237-5).

[47] Thomas P. Ference, James A. Stoner and e. Kirby warren the academy of managementreview vol. 2, no. 4 (oct., 1977), pp. 602-612 published by: academy of managementarticle stable url: http://www.jstor.org/stable/257512.Trainingand developmentjournal, 44: 28-35.

[48] Tremblay M and Roger A (2004). Career stagnationing reactions: the moderating role of job scope, role ambiguity and participating among canadian managers. International journal of human resource management. 15(6): 996-1017.

[49] Tremblay M, Roger A, Toulouse j (1995). Career stagnation and work attitudes: an empirical study of managers. Journal of human relations, 48 (3):.221-237

[50] Tweed, R.G, white, k., \&lehman, d.r. 2004. Culture, stress, and coping: internally and externally-targeted control strategies of europeancanadians, east asiancanadians, and japanese. Journal of cross cultural psychology, 35: 652 .

[51] Shallams, m.1., mcdaniel, .a.,\&nguyen, n.t. 2006. A meta-analysis of the antecedents and consequences of pay level satisfaction.Journal of applied psychology, 91:

[52] Weiner, B. (2010). Attribution theory. Corsini Encyclopedia of Psychology.

[53] Weiner, B. (2008). Reflections on the history of attribution theory and research: People, personalities, publications, problems. Social Psychology,39(3), 151156.

[54] Wickramasinghe, V., \&Jayaweera, M. (2010). Impact of career plateau and supervisory support on career satisfaction: A study in offshore outsourced IT firms in Sri Lanka. Career Development International, 15(6), 544-561.

\section{Volume 6 Issue 7, July 2017 www.ijsr.net}

